\title{
Properties of A Thiamine Binding Protein Purified from Mung Bean
}

\author{
Dwirini Retno Gunarti ${ }^{1, *}$, Megawati Kartika ${ }^{2}$, Mohamad Sadikin ${ }^{1}$
}

Dwirini Retno Gunarti ${ }^{1, *}$, Megawati Kartika², Mohamad Sadikin'

'Departement Biochemistry and Molecular Biology, Faculty of Medicine, University of Indonesia, Jl. Salemba Raya No. 6, Jakarta 10430, INDONESIA.

${ }^{2}$ Master Program in Biomedical Science,

Faculty of Medicine, University of Indonesia, INDONESIA.

\section{Correspondence}

\section{Dwirini Retno Gunarti}

Department of Biochemistry and Molecular Biology, Faculty of Medicine, University of Indonesia, JI. Salemba Raya No. 6, Jakarta 10430, INDONESIA.

E-mail: rinairet@gmail.com

\section{History}

- Submission Date: 21-11-2019;

- Review completed: 01-01-2020;

- Accepted Date: 03-01-2020.

DOI : 10.5530/pj.2020.12.41

Article Available online

http://www.phcogj.com/v12/i2

Copyright

(C) 2020 Phcogj.Com. This is an openaccess article distributed under the terms of the Creative Commons Attribution 4.0 International license.

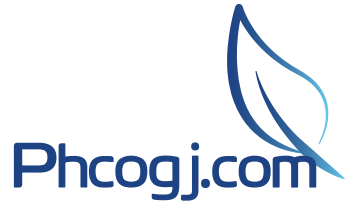

\begin{abstract}
Thiamine (vitamin B1) was the first B vitamin which has been identified. It serves as a cofactor for several enzymes involved in energy metabolism. The laboratory test against thiamine deficiency can be done by measuring thiamine levels in the blood. The aim of this study was to identify the stability and the binding activity characters of TBP. The equilibrium dialysis technique was used to see the factors affecting the bond between TBP and thiamine. The MBTBP concentration of post-chromatographic affinity resulted from dilution of lyophilisate was stable for 30 days at $-20^{\circ} \mathrm{C}$ and 3 days at $4^{\circ} \mathrm{C}$. The optimal $\mathrm{pH}$ for binding MBTBP to thiamine was 7.5. Alkylation with iodoacetic acid decreased the binding capacity of TBP which suggested the presence of a-SH or imidazol group in its active site. The importance of disulfide bridge was proven by decreasing of Thiamine binding capacity of TBP after $\beta$-mercaptoethanol treatment. This binding activity was also affected by oxidizing agents, but it was less affected by calcium ions and heavy metals.
\end{abstract}

Key words: Thiamine; Mung bean thiamine binding protein (MBTBP); Binding capacity.

\section{INTRODUCTION}

Vitamin B1 is also known as thiamine. The chemical name for this water soluble vitamin is 3-[(4-amino-2-methyl-5-pyrimidinyl)methyl]-5(2-hydroxyethyl)-4-methylthiazolium. Thiamine consists of a pyrimidine ring and a thiazole ring, which are coupled by a methylene bridge. ${ }^{1}$

Thiamine is an essential molecule for all life forms. It serves as a cofactor for several enzymes involved in energy metabolism. These enzymes include the pyruvate dehydrogenase, $\alpha$-ketoglutarat dehidrogenase, and the transketolase. In the nervous system thiamine is needed for the stimulation of nerve cells, including g-amino butyric acid (GABA), glutamate, and aspartate. ${ }^{2,3}$

The majority of thiamine in serum is bound to specific proteins. A specific binding protein called thiamine-binding protein (TBP). ${ }^{4}$ Gunarti ${ }^{5}$ showed isolation, purification, characterization of TBP derived from mung beans, which suggested the ability of TBP to measure serum thiamine levels base on principle analogous to enzyme linked immunosorbent assay (ELISA). In this study, MBTBP isolated and obtained from the fraction of affinity chromatography results were $1,446 \mathrm{mg} /$ $\mathrm{mL}$ and its molecular weight was $103,83 \mathrm{kDa}$. The results of bioinformatics analysis and equilibrium dialysis showed every molecule of MBTBP can bind four molecules of thiamine. ${ }^{5}$ The results of the experiment showed that MBTBP can be used for measurement of thiamine in biological fluids using ELPLBA method. However, the detailed characters of the TBP are not all described yet.

Some of TBPs physicochemical properties should be well known before used of as a reactant in a specific assay. The aim of this researchwas to identify physicochemical characters of TBP, such as the influence of temperature and storage time on MBTBP stability, effect of $\mathrm{pH}$ to its thiamine binding capacity, the need of ionic calcium, the role of disulfide bridge and also the effect of alkylating agent, oxidation and heavy metals on bonds between MBTBP and thiamine.

\section{MATERIALS AND METHODS}

\section{Materials}

Mung Bean Thiamine Binding Protein (MBTBP) used was the result of post-affinity chromatography with levels of $1446 \mu \mathrm{g} / \mathrm{mL}$ that had been identified and analyzed. $\mathrm{KH}_{2} \mathrm{PO}_{4}, \mathrm{Na}_{2} \mathrm{HPO}_{4}, \mathrm{NaCl}, \mathrm{NaOH}$, BSA, sodium EDTA, iodoacetate, hydrogen peroxide, $\beta$-mercaptoethanol, $\mathrm{HgCl}_{2}, \mathrm{AgNO}_{3}$, thiamine, buffer sulphate, dialysis tubing cellulose membrane was purchased from Sigma-Aldrich.

\section{Methods}

\section{Protein assay}

Concentration of protein was determined by the method of Warburg-Christian using bovine serum albumin as the standard.

Effect of temperature and storage time on MBTBP stability

MBTBP powder was known to be concentrated and diluted to a concentration of $250 \mu \mathrm{g} / \mathrm{mL}$ in aliquoting and stored at $-20^{\circ} \mathrm{C}, 4^{\circ} \mathrm{C}$ and $37^{\circ} \mathrm{C}$ with storage time of 3 days, 7 days, 14 days and 30 days. ${ }^{6,7}$ Furthermore, protein levels were measured using a standard BSA curve. 


\section{Effect of $\mathrm{pH}$}

The effect of $\mathrm{pH}$, was determined by equilibrium dialysis and $\mathrm{pH}$ range used was 6.0-9.0. The binding capacity of MBTBP was determinated by equilibrium dialysis. At the end of this period, the thiamine concentration in dialysate was measured by spectrophotometer at the $\lambda$ $280 \mathrm{~nm}$. A control was used in this experiment, on to $1 \mathrm{~mL}$ of distilled water was added $1 \mathrm{ml}$ of $50 \mu \mathrm{g} / \mathrm{mL}$ thiamine. The mixtures were dialyzed against $50 \mathrm{ml}$ phosphate buffer $\mathrm{pH} 7.2$ at room temperature $\left(25^{\circ} \mathrm{C}\right)$ for 2 hours. Role of $\mathrm{pH}$, on to $1 \mathrm{ml}$ of $250 \mu \mathrm{g} / \mathrm{mL}$ TBP was added $1 \mathrm{ml}$ of 50 $\mu \mathrm{g} / \mathrm{mL}$ thiamine and $1 \mathrm{ml}$ of phosphate buffer $\mathrm{pH}$ 6.0. The experiment was repeated using the same amount of TBP, thiamine and phosphate buffer but with the other $\mathrm{pH}, 6.5,7.0,7.5,8.0,8.5,9.0$. All the seven mixtures were placed in dialysis bag and dialyzed at room temperature for 2 hours against $50 \mathrm{ml}$ phosphate buffer with the other $\mathrm{pH}$ of $6.0,6.5$, $7.0,7.5,8.0,8.5,9.0 .^{8}$

Effect calcium ion, alkylation, reduction, oxidation, and heavy metals agents on bonds between MBTBP and thiamine

Two controls were used in this experiment. The first was $1 \mathrm{~mL}$ solution of $20 \mu \mathrm{g} / \mathrm{mL}$ thiamine in $1 \mathrm{~mL}$ of distilled water, the other was $1 \mathrm{ml}$ solution of $20 \mu \mathrm{g} / \mathrm{mL}$ thiamine in $1 \mathrm{~mL}$ of $144,6 \mu \mathrm{g} / \mathrm{mL}$ MBTBP. At the end of this period, the thiamine concentration in dialysate was measured by spectrophotometer at the $\lambda 280 \mathrm{~nm} .^{9}$

\section{Role of calcium}

The role of calcium ion was performed using sodium EDTA. The binding capacity of MBTBP was determinated by equilibrium dialysis. On to $1 \mathrm{ml}$ of $144,6 \mu \mathrm{g} / \mathrm{mL}$ MBTBP was added $0.74 \mathrm{mg}$ of sodium EDTA, followed by $1 \mathrm{ml}$ of $20 \mu \mathrm{g} / \mathrm{mL}$ thiamin. The mixtures were dialyzed against $50 \mathrm{ml}$ phosphate buffer $\mathrm{pH} 7.5$ at room temperature $\left(25^{\circ} \mathrm{C}\right)$ for 2 hours. $^{9}$

\section{Role of-SH groups}

The role of-SH groups was performed using iodoacetic acid as alkylation compound. The binding capacity of MBTBP was determinated by equilibrium dialysis too. On to $1 \mathrm{ml}$ of $144,6 \mu \mathrm{g} / \mathrm{mL}$ MBTBP was added $0,37 \mathrm{mg}$ iodoacetic acid, followed by $1 \mathrm{ml}$ of $20 \mu \mathrm{g} / \mathrm{mL}$ thiamin. The mixtures were dialyzed against $50 \mathrm{ml}$ phosphate buffer $\mathrm{pH} 7.5$ at room temperature $\left(25^{\circ} \mathrm{C}\right)$ for 2 hours.

\section{Role of disulfide bridge}

The role of calcium ion was performed using $\beta$-merkaptoetanol. The binding capacity of MBTBP was determinated by equilibrium dialysis. On to $1 \mathrm{ml}$ of $144,6 \mu \mathrm{g} / \mathrm{mL}$ MBTBP was added $50 \mu \mathrm{L} \beta$-merkaptoetanol, followed by $1 \mathrm{ml}$ of $20 \mu \mathrm{g} / \mathrm{mL}$ thiamin. The mixtures were dialyzed against $50 \mathrm{ml}$ phosphate buffer $\mathrm{pH} 7.5$ at room temperature $\left(25^{\circ} \mathrm{C}\right)$ for 2 hours. ${ }^{9}$

\section{Role of oxidation agent}

The role of oxidation agent was performed using hydrogen peroxyde $\left(\mathrm{H}_{2} \mathrm{O}_{2}\right)$. The binding capacity of MBTBP was determinated by equilibrium dialysis. Onto $1 \mathrm{ml}$ of $144,6 \mu \mathrm{g} / \mathrm{mL}$ MBTBP was added 0,067 $\mathrm{mg} \mathrm{H} \mathrm{O}_{2}$, followed by $1 \mathrm{ml}$ of $20 \mu \mathrm{g} / \mathrm{mL}$ thiamin. The mixtures were dialyzed against $50 \mathrm{ml}$ phosphate buffer $\mathrm{pH} 7.5$ at room temperature $\left(25^{\circ} \mathrm{C}\right)$ for 2 hours. ${ }^{9}$

\section{Role of heavy metalsagents}

The role of heavy metals was performed using $\mathrm{HgCl}_{2}$ and $\mathrm{AgNO}_{3}$. The binding capacity of MBTBP was determinated by equilibrium dialysis. Onto $1 \mathrm{ml}$ of $144,6 \mu \mathrm{g} / \mathrm{mL}$ MBTBP was added $0,54 \mathrm{mg} \mathrm{HgCl}_{2}$, onto

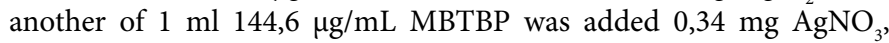

followed by $1 \mathrm{ml}$ of $20 \mu \mathrm{g} / \mathrm{mL}$ thiamin. The mixtures were dialyzed against $50 \mathrm{ml}$ phosphate buffer $\mathrm{pH} 7.5$ at room temperature $\left(25^{\circ} \mathrm{C}\right)$ for 2 hours.

\section{RESULT}

\section{Determination of MBTBP Concentration}

Protein was measured at a wavelength of $280 \mathrm{~nm}$ with BSA as standard. The soluble MBTBP concentration was $1,115 \mathrm{mg} / \mathrm{mL}$.

Effect of temperature and storage time on MBTBP stability

The MBTBP concentration was stablefor 30 days at $-20^{\circ} \mathrm{C}$ and 3 days at $4^{\circ} \mathrm{C}$. The dissolved solution of MBTBP wasunstable at $30^{\circ} \mathrm{C}$ (Figure 1).

\section{Effect of $\mathrm{pH}$}

The binding activity between MBTBP and thiamine is influenced by $\mathrm{pH}$. As shown in Figure 2, the binding activity of MBTBP at various $\mathrm{pH}$ value indicated that the optimum $\mathrm{pH}$ is 7.5 .

Effect calcium ion, alkylation, reduction, oxidation, and heavy metals agents on bonds between MBTBP and thiamine

The addition of EDTA $\left(\mathrm{Ca}^{2+}\right.$ chelating agent), were less affect the binding between TBP and thiamine (Figure 3 ).

However, the addition of iodoacetate (alkylating agent), $\beta$ mercaptoethanol (reduction agent) and $\mathrm{H}_{2} \mathrm{O}_{2}$ (oxydating agent), decreased the binding capacity of TBP to thiamine (Figures 4-6).

The addition of $\mathrm{HgCl}_{2}$ and $\mathrm{AgNO}_{3}$ were less affect the binding between TBP and thiamine (Figures 7 and 8 ).

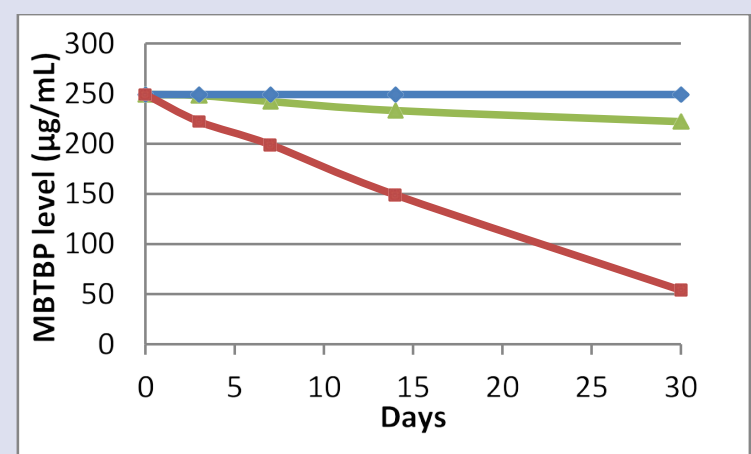

$\longrightarrow$ Suhu $40 \mathrm{C} \longrightarrow$ Suhu $-200 \mathrm{C} \longrightarrow$ suhu $370 \mathrm{C}$

Figure 1: Comparison of MBTBPstorage conditions.

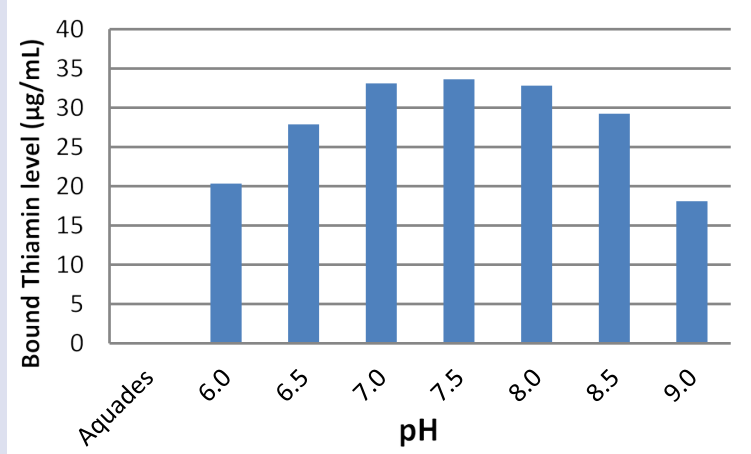

Figure 2: Effect of pH on MBTBP activity binds to thiamine. 


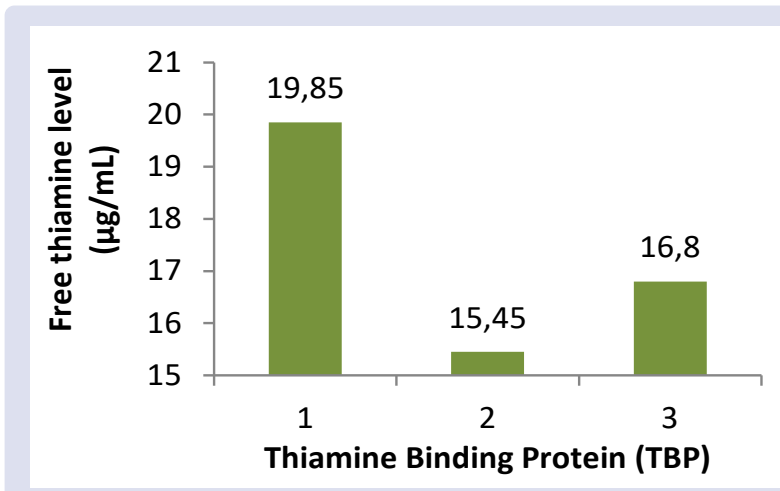

Figure 3: Free thiamine level after binding of TBP with EDTA, 1 Distilled water control, 2. TBP control, 3. TBP with EDTA.

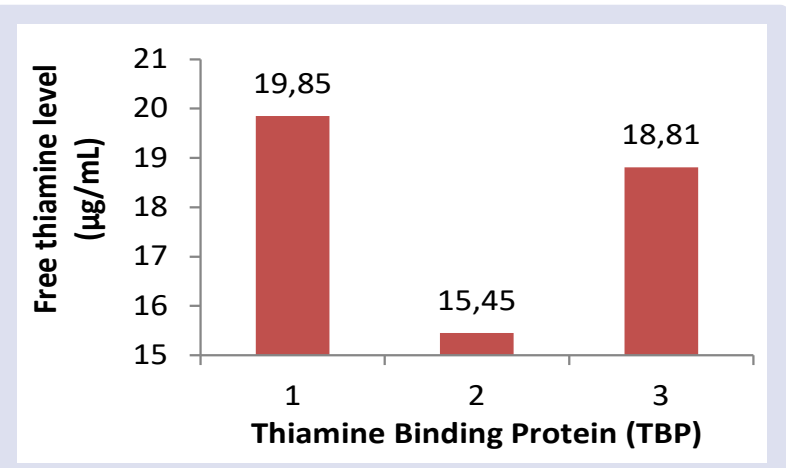

Figure 4: Free thiamine level after binding of TBP with iodoacetate, 1. Distilled water control, 2. TBP control, 3. TBP with iodoacetate.

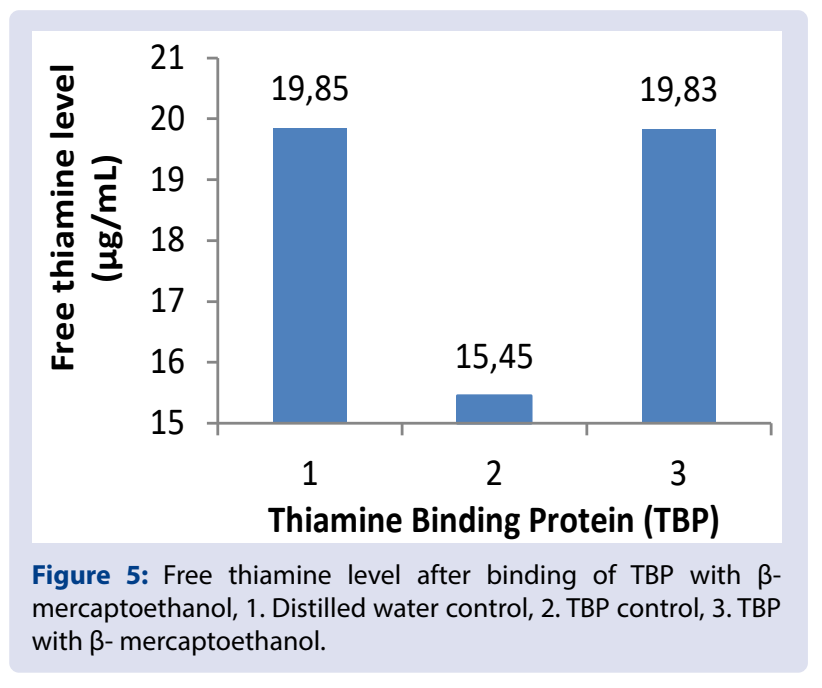

\section{DISCUSSION}

Purified proteins often need to be stored for an extended period of time while retaining their original structural integrity and/or activity. ${ }^{10}$ From the previous study, protein levels after purification were $1,446 \mathrm{mg} / \mathrm{mL}$. The extent of storage 'shelf life' can vary from a few days to more than a year and is dependent on the nature of the protein and the storage conditions used. . $^{70}$

The protein concentration from dilution of lyophilisate was $1,015 \mathrm{mg} /$ $\mathrm{mL}$. Protein was assayed following the method of Warburg-Christian $(\lambda$ $280 \mathrm{~nm}$ ) with bovine serum albumin as a standard. ${ }^{5}$ The lyophilization allows for long-term storage of protein with very little threat of

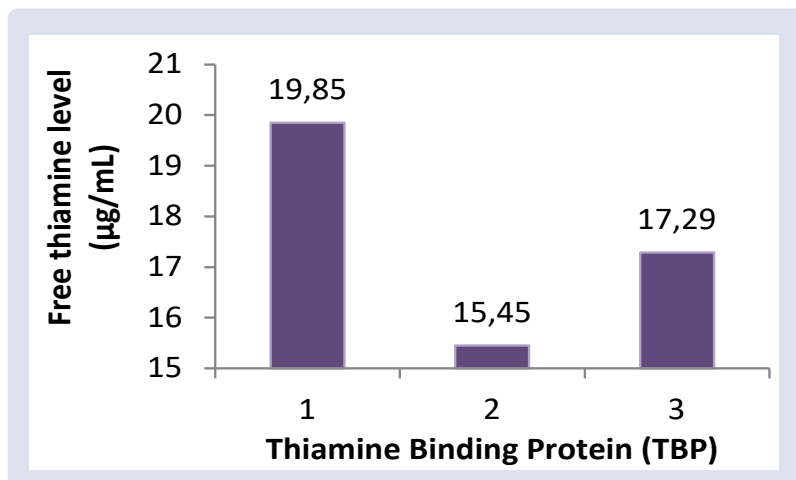

Figure 6: Free thiamine level after binding of TBP with hydrogen peroxyde $\left(\mathrm{H}_{2} \mathrm{O}_{2}\right), 1$. Distilled water control, 2. TBP control, 3. TBP with hydrogen peroxyde $\left(\mathrm{H}_{2} \mathrm{O}_{2}\right)$.

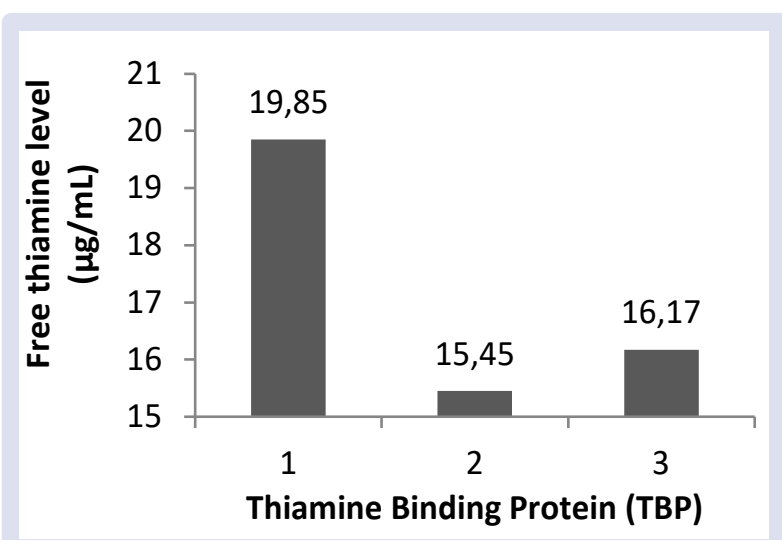

Figure 7: Free thiamine level after binding of TBP with $\mathrm{HgCl}_{2}, 1$. Distilled water control, 2. TBP control, 3. TBP with $\mathrm{HgCl}_{2}{ }^{\text {a }}$

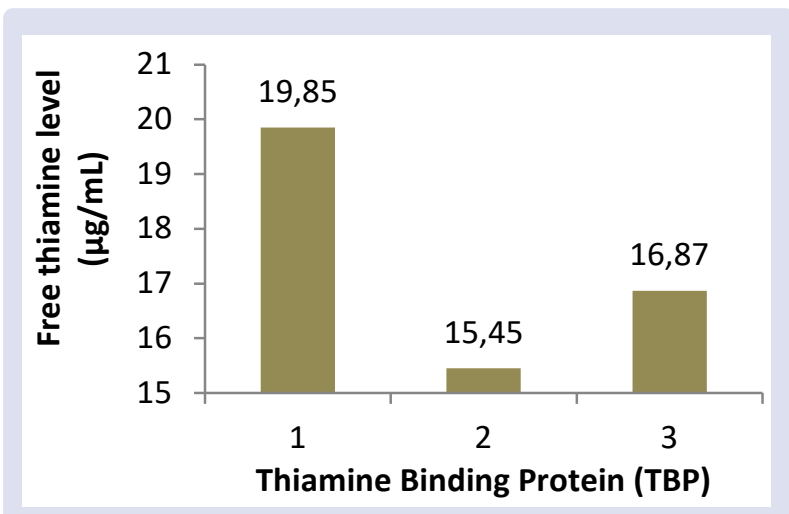

Figure 8: Free thiamine level after binding of TBP with $\mathrm{AgNO}_{3^{\prime}} 1$. Distilled water control, 2. TBP control, 3. TBP with $\mathrm{AgNO}_{3}$.

degradation, but the protein must be reconstituted before use and may be damaged by the lyophilization process. ${ }^{6}$

Optimal conditions for storage are distinctive to each protein. ${ }^{10}$ The TBP of lyophilisate dilution when stored at $4^{\circ} \mathrm{C}$ was stable up to day three and thereafter a slower concentration decrease occurred than when stored at $30^{\circ} \mathrm{C}$. Generally, proteins are best stored at $\leq 4^{\circ} \mathrm{C}$. such proteins may not be stable for more than a few days or weeks. Storage at room temperature often leads to protein degradation and/ or inactivity, commonly as a result of microbial growth, for short term storage ( 1 day to a few weeks). ${ }^{7,10}$ The TBP oflyophilizate dilution results was more stable when stored at $-20^{\circ} \mathrm{C}$. Frozen at $-20^{\circ} \mathrm{C}$ or $-80^{\circ} \mathrm{C}$ is the more common form of cold protein storage. Because freeze-thaw cycles 
decrease protein stability, samples for frozen storage are best dispensed and prepared in single-use aliquots so that, once thawed, the protein solution will not have to be refrozen.

Like the TBPs of sesame seeds ${ }^{11}$, the mung bean TBP exhibits the maximal thiamine-binding activity at $\mathrm{pH} 7,5$. In contrast, the thiaminebinding by TBPs from buck wheat ${ }^{8}$, sun flower ${ }^{11}$, wheat germ ${ }^{12}$, Maize seeds ${ }^{13}$ and rice ${ }^{14}$ are optimal at $\mathrm{pH}$ 8.0-9.0.

Measurement of binding capacity MBTBP against thiamine through equilibrium dialysis showed a value of $1: 4 .^{5}$ To bind thiamine, the TBP apparently need $\mathrm{Ca}^{2+}$ ion. This conclusion was obtained from the experiment with EDTA. With EDTA, TBP bound practically the less amount of thiamine, which means the presence of $\mathrm{Ca}^{2+}$ ion is essential for the binding.

The experiment with iodoacetic acid showed that binding activity of TBP decrease significantly. Iodoacetic acid is well-known as an alkylating agent. One of the binding sites of MBTBP to thiamine is histidine. ${ }^{7}$ The addition of iodoacetate compound causes alkylation in MBTBP histidine residues. This means that histidine residues play a role in the thiamin binding process by MBTBP. Part of amino acid histidine could be alkylated by iodoacetic acid. ${ }^{15,16}$

$\beta$-Mercaptoethanol is known for reducing disulfide bridge in any protein. This research found that addition of this reducing agent decreased significantly the binding activity of TBP (almost $100 \%$ as compared to distilled water control). It has been reported that TBP has several disulfide bridges. The experiment showed clearly that the maintaining of the disulfide bridge for the binding capacity of TBP is very important. The Subandrate research (2011) found that addition of this reducing agent decreased significantly the binding activity of TBP.

Hydrogen peroxide $\left(\mathrm{H}_{2} \mathrm{O}_{2}\right)$ is a strong oxidizing compound. This oxidizing compound can cause the oxidation of some amino acid residues and protein polymerization. ${ }^{17}$ The test results showed unbound thiamine MBTBP of $41 \%$ when compared to control. Amino acid residues that are susceptible to oxidation reactions are histidine and tyrosine.${ }^{17}$ The result of Gunarti's research (2016) is the binding site of MBTBP1 with thiamine i.e., threonine, tyrosine, arginine, histidine and MBTBP2 with thiamine i.e., tyrosine, arginine and glutamine.

Heavy metals like $\mathrm{Hg}^{+2}, \mathrm{Ag}^{+1}$, may also disrupt disulfide bonds because of their high affinity and attraction for sulfur and will also lead to the denaturation of proteins. Since salts are ionic, they disrupt salt bridges in proteins. The reaction of a heavy metal salt with a protein usually leads to an insoluble metal protein salt. ${ }^{17-27}$

\section{ACKNOWLEDGEMENTS}

This research was partly funded by the PITTA UI (PublikasiInternasionalTerindeksUntukTugasAkhirMahasiswa) grant 2017. The authors acknowledge the supports of biochemistry and biology molecular for the laboratory and technical support.

\section{REFERENCES}

1. Fattal-Valevski A. Thiamine (vitamin B1). Journal of Evidence-Based Complementary \& Alternative Medicine. 2011;16(1):12-20.
2. Singleton $\mathrm{CK}$, Martin PR. Molecular mechanisms of thiamine utilization. Journal of Current Molecular Medicine. 2001;1:197-207.

3. Stump SE, Mahan LK. Krause's, Food, nutrition and diet therapy. WB Saunders Elsevier. 2000.

4. Combs Jr GF. The vitamins: Fundamental Aspects in nutrition and health (3rd ed.). Ithaca, NY: Elsevier Academic Press. 2008;ISBN 978-0-12-183493-7.

5. Gunarti DR. Analisis protein ikat tiamin bekatul kacang hijau sebagai usaha pengembangan teknik pengukuran tiamin dalam cairan biologis [Disertasi]. University of Indonesia. 2016.

6. www.indiana.edu/ Ichenlab/protocol_files/protein_storage.pdf. OPierce Biotechnology, Inc.9/2005.

7. Ogundele MO. Techniques for the storage of human breast milk: implication for anti-microbial function and safety of stored Milk. Eur J Pediatr. 2000;159:75997.

8. Mitsunaga T, Matsuda M, Shimizu M, Iwashima A. Isolation and properties of a thiamine-binding protein from buckwheat seed. J.Cereal Chem. 1986;63(4):3325.

9. Subandrate, Gunarti DR, Sadikin M. Properties of folate binding protein purified from cow's milk. Hayati Journal of Biosciences. 2012;19(3):105-9.

10. Simpson RJ. Stabilization of proteins for storage. Cold Spring Harb Protoc Review.

11. Shimizu M, Inaba K, Yoshida T, Toda T, Iwashima A, Mitsunaga T. Purification and properties of thiamine-binding proteins from sesame seed. Plant Physiology and Biochemistry. 1995;93:93-8.

12. Watanabe K, Konishi A, Mitsunaga T. Molecular characteristics of thiaminbinding protein from sunflower seeds. Plant Physiology and Biochemistry. 2002;40(5):417-21.

13. Sylwia A, Rapala-Kozik M, Kozik AM. Purification and preliminary characterisation of a thiamine binding Protein from Maize Seeds. Plant Physiology and Biochemistry. 1999;156:635-9

14. Shimizu M, Yoshida T, Toda T, Iwashima A, Mitsunaga T. Isolation of a thiaminebinding protein from rice germ and distribution of similar proteins. Bioscience, Biotechnology, and Biochemistry. 1996;60(3):453-7.

15. Fruchter RG, Crestfield AM. The specific alkylation by iodoacetamide of histidine-12 in the active site of ribonuclease. J Bio Chem. 1967;242:5807-12.

16. Chase JFA, Tubbs PK. Specific alkylation of a histidine residue in carnitine acetyltransferase by bromoacetyl-Lcarnitine. Biochem J. 1970;116:713-20.

17. CE. Virtual chembook. Depertment of chemistry elmhurst IL. Elmhurst College. 2003.

18. Riyanto. Validasi \& verifikasi metode uji. Depublish. Yogyakarta. 2014:32-33.

19. Bötticher B. Simple rapid determination of thiamin by a HPLC method in foods, body fluids, urine and faeces. Int J Vitam Nutr Res. 1986;56(2):155-9.

20. Burgess GW. Prinsip dasar ELISA dan variasi konfigurasinya. Di dalam: Artama WT, penerjemah; Burgess GW, editor. Teknologi ELISA dalam diagnosis dan penelitian. Yogyakarta: Gadjah Mada University Press. Terjemahan dari: ELISA technology in Diagnosis and Research. 1995.

21. Crowther JR. The ELISA guide book methods in molecular biology. The international atomic energy agency. Vienna. Austria. Humana Press Inc Totawa, New Jersey. 2001.

22. Fennema. Food chemistry. 3th Edition. New York: Marcel Dekker, Inc. 1996.

23. Gunarti DR, Sadikin M, Rahmi H. Isolation and purification of thiamine-binding protein from mung bean. Hayati Journal of Biosciences. 2013;20(1).

24. Lequin RM. Enzyme immunoassay (EIA)/enzyme-linked immunosorbent assay (ELISA). Clinical Chemistry. 2005;51(12):2415-8.

25. Murray RK, Grannu DK, Mayes PA, Rodwell WW (editor). Harper's illustrated biochemistry. Edisi ke 27. New York: McGraw-Hill. 2006:516-7.

26. Sudarmadji S. Teknik analisa biokimiawi. Yogyakarta: Liberty. 1996.

27. Weber W, Kewitz H. A Determination of thiamine in human plasma and its pharmacokinetics. Eur J Clin Pharmacol. 1985;28(2):213-9. 


\section{GRAPHICAL ABSTRACT}
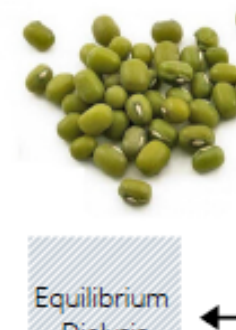
Dialysis
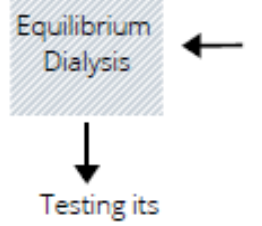

Thiamine Bond

Against<smiles>CC1C[SeH]1</smiles>

1. Temp. and Time; 2. pH; 3. Alkylation; 4.Calcium; 5. -SH Groups; 6. Disulfide Bridge;

7. Oxidation Agent; 8. Heavy Metal Agents

\section{Several Steps}

of Isolation

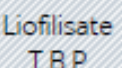

Liofilisation

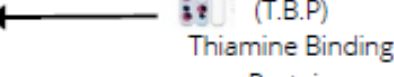

Protein

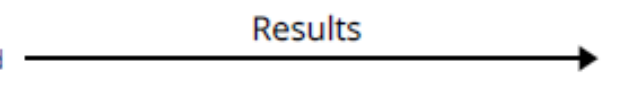

\section{SUMMARY}

T.B.P which has been isolated from mung beans can be used as a laboratory test for thiamine deficiency. The aim of this research was to identify the stability and the binding activity characters of TBP. The equilibrium dialysis technique was used to see the factors affecting the bond between TBP and thiamine. In this research, temperature, time, alkylation, calcium, -SH groups, disulfide bridge, oxidation, and heavy metal shown to be decreasing the stability of M.B.T.B.P bonds with thiamine.

\section{ABOUT AUTHORS}

Dwirini Retno Gunarti obtained her doctorate degree from Biochemistry and molecular biology department in the faculty of medicine, University of Indonesia. She has lectured and researched in biochemistry and molecular biology of faculty of medicine for more than 30 years.

Megawati Kartika is a master in biochemistry from University of Indonesia, Jalan Salemba Raya No. 6, Jakarta Pusat, 10430, Indonesia.

Mohammad Sadikin is a professor in biochemistry from University of Indonesia, Jalan Salemba Raya No. 6, Jakarta Pusat, 10430, Indonesia.

Cite this article: Gunarti DR, Kartika M, Sadikin M. Properties of A Thiamine Binding Protein Purified from Mung Bean. Pharmacog J. 2020;12(2):266-70. 